\title{
FORMATION OF COPPER MATTE FROM COPPER SLAG USING GYPSUM FROM HYDROMETALLURGICAL PLANTS
}

\author{
Michel Kalenga WA KALENGA \\ Department of metallurgy, School of mining, metallurgy and chemical engineering, Faculty of Engineering \\ and Built Environment, University of Johannesburg, South Africa; michelk@uj.ac.za
}

https://doi.org/10.37904/metal.2019.926

\begin{abstract}
As primary resources become more and more complex in their chemical composition and some places poor in their valuable metals in the ore secondary sources like slag phases from the production processes get in the focus of the metal industry. Currently about $70 \%$ of copper slag remains is ineffectively utilized. Hence the need of their treatment and attend to ecological environment problems that they might cause. The current study focuses on the recovery of copper from copper slag by using gypsum formed during impurities removal in hydrometallurgical plants. The fayalitic slag was provided by Gecamines in the DR Congo and the gypsum from the small scale hydrometallurgical plant in Lubumbashi in the Democratic Republic of Congo. The gypsum played a double role of sulphur provider and flux. The aimed basicity of the slag through the addition of gypsum was 1. XRF, XRD were used to characterize gypsum whereas the slag and the subsequent products analysed with XRD, XRF and SEM. The working temperature was set at $1400{ }^{\circ} \mathrm{C}$ for two hours with CO blown at 0.2 $\mathrm{I} / \mathrm{min}$ in the furnace to allow copper to be freed from other oxides and form a sulfide. Graphite crucible was used in an alumina tube furnace. Coke was added to limit crucible reaction. The heating rate was $7^{\circ} \mathrm{C} / \mathrm{min}$. Results confirmed the presence of covellite and FeS stating matte effectively formed while anorthite was present in the slag confirming the influence of the $\mathrm{CaO}$ added through gypsum on the final slag produced.
\end{abstract}

Keywords: Matte formation, copper slag, gypsum

\section{INTRODUCTION}

With the depletion of mines, the treatment of slag containing valuable metals is unavoidable. Piles of slags are found in different parts of the world with some that can be recycled to recover valuable metals that they contain. The grade of some of them is even higher grade than the run of mines. The current study made use of a copper slag that had copper content that is competitive as opposed to some copper ores run of mines. Previous studies where copper slag was used in reductive conditions in presence of a sulfurizing agent namely waste gypsum that contained basanite and gypsum. Results have shown that copper matte formed with some cobalt sulphides present as well as iron sulphides and that hedenbergite, magnetite and fayalite were present in the subsequent slag [1]. Previous work on the same sample as the one used in the current study was conducted. A smelting under reductive conditions with the use of $2.5 \%$ and $5 \%$ of coke led to a recovery of copper, cobalt and zinc for lower carbon whereas at higher carbon percentage it was found that zinc escaped in the fumes [2]. Some other investigations on slags included the bioleaching for the recovery of valuable metals. This was to minimize environmental issues $[3,4]$. The sulfurization of nickel slag using gypsum from hydrometallurgical plant has been investigated. Results showed that nickel sulphides effectively formed [5]. Studies have shown that $\mathrm{CaO}$ dissociates into $\mathrm{Ca}^{2+}$ and $\mathrm{O}^{2-}$ and $\mathrm{CaO}$ reduces the viscosity in the molten slag because primarily, the complex polymeric anions $\mathrm{Si}_{x} \mathrm{O}_{y} \mathrm{z}^{-}$absorb $\mathrm{O}^{2-}$ and and their complex compounds decompose into simpler anions. The size of the polymeric anions is reduced resulting in the low viscosity of the slag [6]. To promote the mineralization of valuable metals contained in a copper slag, a modification of a copper slag was conducted. It was found that the change of basicity improved the beneficiation of copper and iron [7]. A study on copper recovery by sulfation roasting in presence of sulfuric acid was conducted. The temperature ranged from 150 and $800^{\circ} \mathrm{C}$. The results showed that the extraction of copper was simultaneous with iron extraction 
[8]. Similar investigations were conducted at $500{ }^{\circ} \mathrm{C}$ with a recovery close to $90 \%$ [9]. A copper smelter slag was treated in presence of ammonia. It was found that the mathematical models established were successful in predicting the response [10]. The investigation on a possible recovery of copper from a reverberatory copper slag was conducted. It was found that parameters such as concentration of sulfuric acid, amount of distilled water and the size particles were influential on copper recovery [11]. Although the amorphous structure of the smelter copper slag made its leaching difficult, an early investigation led to good results avoiding the formation of silica gel with the use of hydrogen peroxide [12]. A study on the recovery of base metals namely copper, cobalt and zinc was conducted on copper smelter and converter slags. It was found that acid roasting followed by hot water leaching was efficient in recovering the above mentioned base metals [13].

The current investigation focused on the possibility of copper matte formation with the use of gypsum that was produced during iron removal from sulphates solutions. This was to address the environmental concerns of disposing the gypsum that would degrade the surroundings with a possible formation of sulfuric acid and the slag for storage space.

\section{EXPERIMENTAL PROCEDURE}

\section{Materials}

A copper slag from a water jacket furnace was used as source of copper since the slag was of good grade in copper. Gypsum collected from hydrometallurgical plant during iron removal from sulphate solutions used as sulfurizing agent and basicity modifier. Coke containing $83 \%$ of fixed carbon was used as additional reductant.

\section{Methodology}

The slag, gypsum and coke were mixed and milled together for 15 minutes to improve the homogeneity of the feed. Experiments were conducted at $1400{ }^{\circ} \mathrm{C}$ using an alumina tube furnace heated with silicon carbide elements. As soon as the set temperature was reached, it was kept for two hours and the furnace was switched off thereafter till room temperature. The feed and the products were analyzed using XRF, XRD and SEM. The basicity of the feed was adjusted to 1 through the addition of gypsum. A graphite crucible was used for the experiments. Five per cent of coke was added to enhance the reduction conditions and to limit the reaction between the graphite crucible and the slag. Carbon monoxide was also blown inti the furnace to make sure reduction took place to favor the formation of matte.

\section{RESULTS AND DISCUSSION}

\subsection{Head sample and coke}

The chemical composition of the slag is provided in Table 1 below.

Table 1 Chemical composition of the copper slag

\begin{tabular}{|l|c|c|c|c|c|c|c|}
\hline Element/Compound & $\mathrm{SiO}_{2}$ & $\mathbf{C a O}$ & $\mathbf{M g O}$ & $\mathbf{A l}_{2} \mathbf{O}_{3}$ & $\mathbf{F e}$ & CuO & Basicity \\
\hline (wt $\%)$ & 31.1 & 16.1 & 4.9 & 6.2 & 37.7 & 3.60 & 0.56 \\
\hline
\end{tabular}

Basicity $=(\% \mathrm{CaO}+\% \mathrm{MgO}) /\left(\% \mathrm{SiO}_{2}+\% \mathrm{Al}_{2} \mathrm{O}_{3}\right)$

The chemical composition of the slag revealed that the amount of copper oxide was around $3.6 \%$ which was an indication of a good source of copper. Also, the amount of iron in the slag was considerably high, which had a positive impact for the formation of copper matte. The basicity of the slag of the slag confirmed that it was a fayalitic slag since the amount of silica content was high. The addition of gypsum had therefore a considerable impact on the basicity of the slag. 
The XRD results are shown in Figure 1 below. These results were obtained through the decomposition of the picks using the software OrginPro 8.5.

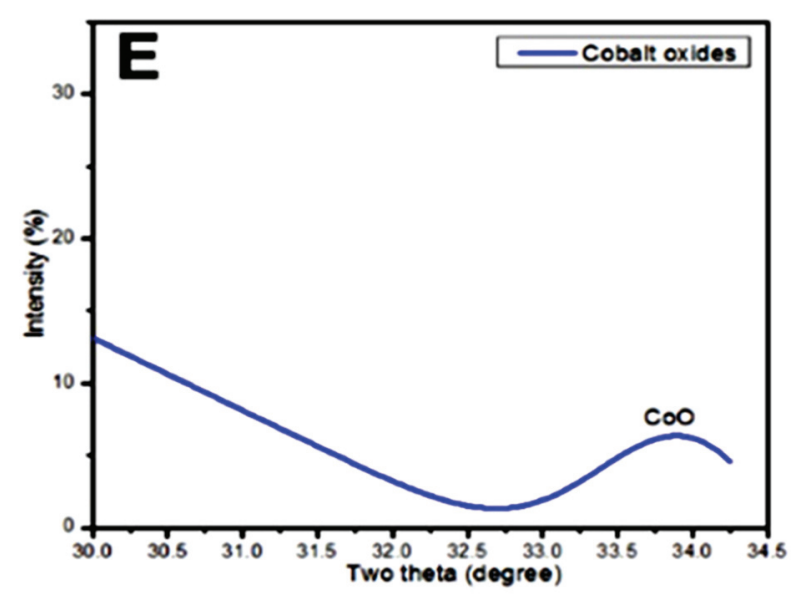

(a)

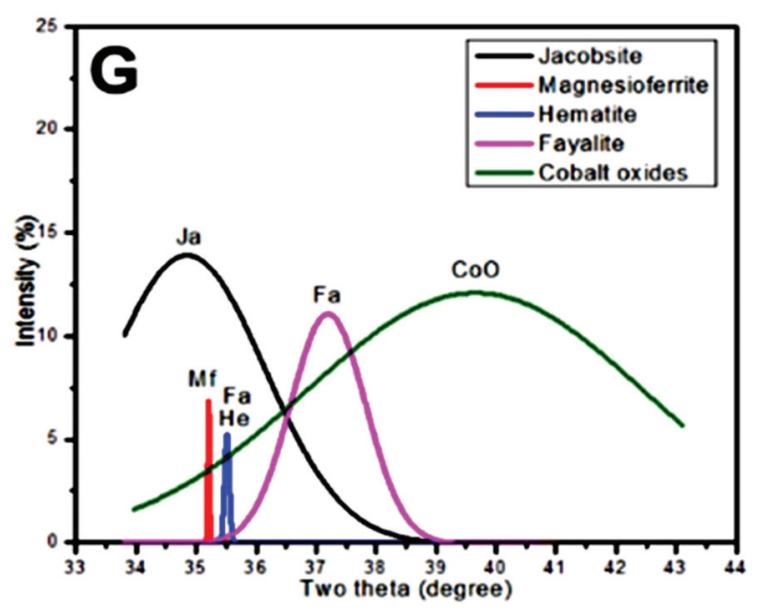

(b)

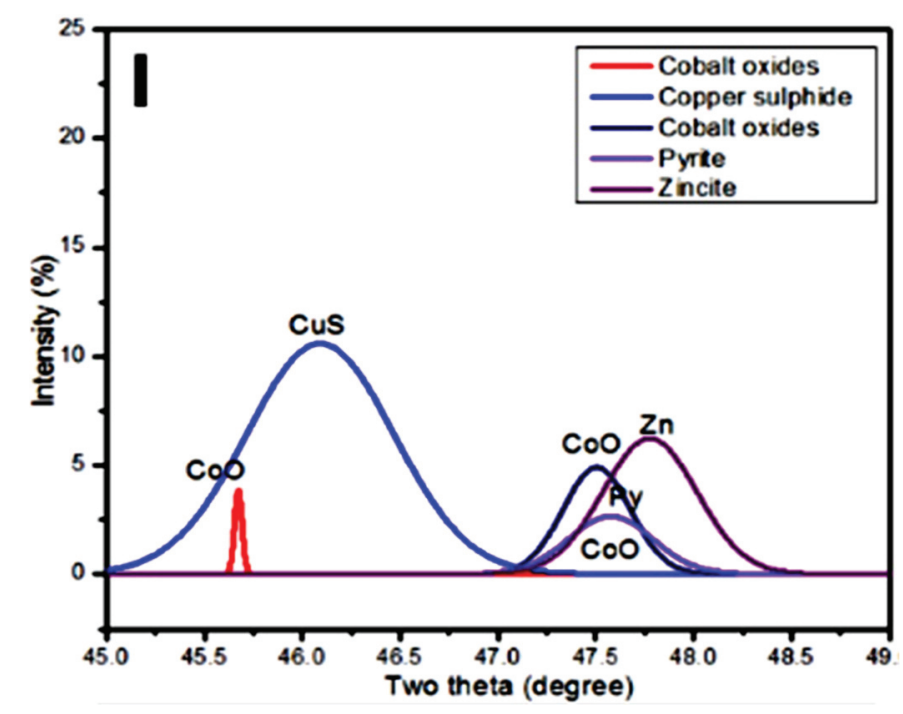

(c)

Figure $1(\mathbf{a}, \mathbf{b}, \mathbf{c})$ Decomposition of picks obtained from XRD [14]

The presence of cobalt oxides, hematite, fayalite, jacobsite, pyrite, zincite copper sulphide, magnesioferrite (Mf) was confirmed. The head sample was from water jacket furnace where copper matte was produced. Most probably some matte was trapped in the slag when the slag was being tapped. The sulphides found in the sample were therefore presumably from the entrained matte in the slag during tapping from the water- jacket furnace. Although copper oxide was not detected, the chemical composition did confirm its presence.

The coke that was used in the current investigation has the analyses provided in Table 2 below.

Table 2 Proximate and ultimate analysis of the coke used

\begin{tabular}{|c|c|c|c|c|}
\hline & \multicolumn{4}{|c|}{ Proximate analysis (AR) (wt\%) } \\
\hline & Fixed C & Volatiles & Ash & Moisture \\
\hline Coke & 83 & 3.9 & 11.7 & 1.79 \\
\hline
\end{tabular}

*AR: As Received, Fixed carbon by difference [100 - (Volatile matter + Moisture + Ash content)] 
From Table 2 it could be noticed that moisture content and volatile matters were relatively low whereas the ash content was above $10 \mathrm{wt} \%$ and fixed carbon $83 \mathrm{wt} \%$.

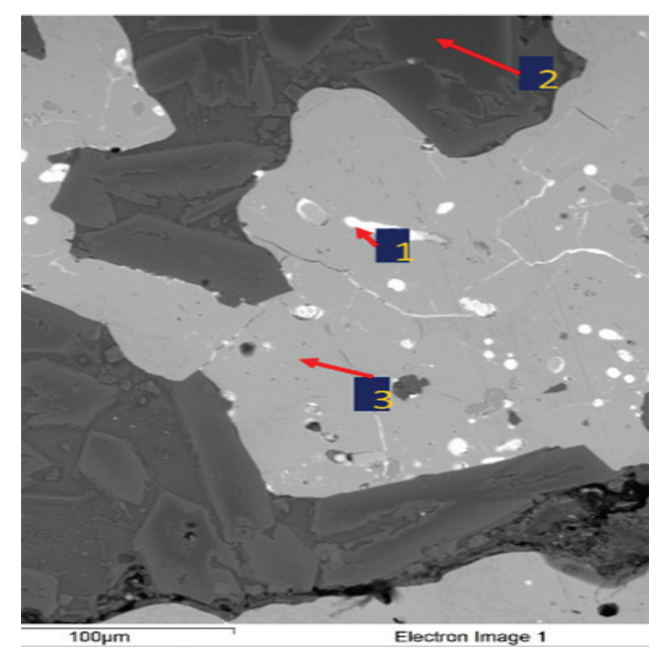

\begin{tabular}{|c|c|c|c|}
\hline Spectrum & $\mathbf{1}$ & $\mathbf{2}$ & $\mathbf{3}$ \\
\hline $\mathbf{C o}$ & - & 6.1 & 0.2 \\
\hline $\mathbf{F e}$ & - & 17.1 & 0.3 \\
\hline $\mathbf{C u}$ & 9.9 & - & 50.1 \\
\hline $\mathbf{Z n}$ & 20.9 & 17.8 & 3 \\
\hline $\mathbf{S i}$ & 30.1 & 25.5 & 20.2 \\
\hline $\mathbf{C a}$ & 9.2 & 7.5 & 2.0 \\
\hline $\mathbf{N i}$ & 1.1 & 3.6 & - \\
\hline $\mathbf{O}$ & 28.8 & 22.4 & 24.1 \\
\hline
\end{tabular}

Figure 2 SEM-EDS spectrum of the slag (wt\%) [14]

From the SEM-EDS analyses presented in Figure 2 above confirmed the presence of copper in the slag. The SEM results suggested that the slag contained more zinc than copper and cobalt.

\subsection{Effect of gypsum on the smelting of copper slag}

The addition of gypsum was aimed at converting the copper oxide and iron oxide present in the slag into sulfides to form matte. The possible mechanism of conversion is provided in the reactions below:

$\mathrm{CaSO}_{4}=\mathrm{CaO}+\mathrm{SO}_{2}+0.5 \mathrm{O}_{2}$

$\mathrm{SO}_{2}+\mathrm{CuO}=\mathrm{CuS}+1.5 \mathrm{O}_{2}$

$\mathrm{SO}_{2}+\mathrm{FeO}=\mathrm{FeS}+1.5 \mathrm{O}_{2}$

The above reactions were favoured by the presence of carbon in the system.

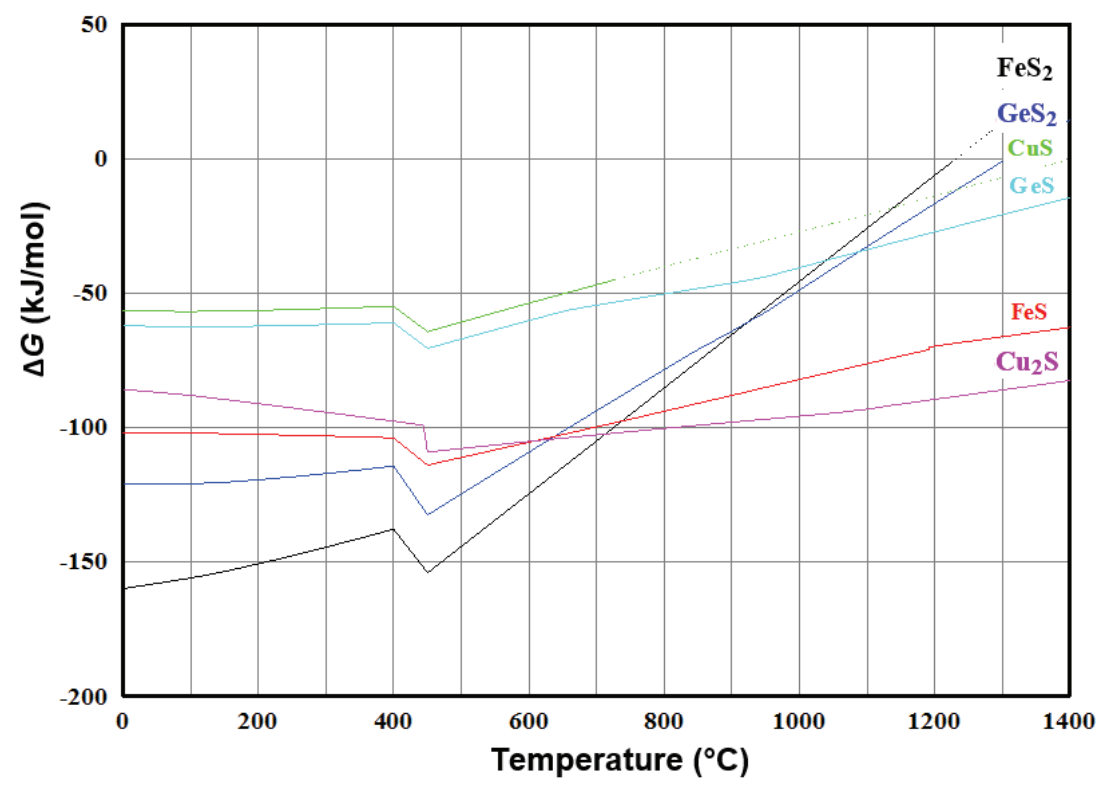

Figure 3 Ellingham diagram 
The Ellingham diagram in Figure 3 was generated using a computing HSC chemistry 5 sofware. This helped to predict the sequence of reactions at the considered working conditions in the prsent study. From the Ellingham diagram above and based on the Gibbs free energy change, undeniably $\mathrm{Cu}_{2} \mathrm{~S}$ thermodynamically formed first, followed by FeS and CuS was last.

The XRD results of the products after smelting are presented in Figure 4 below.

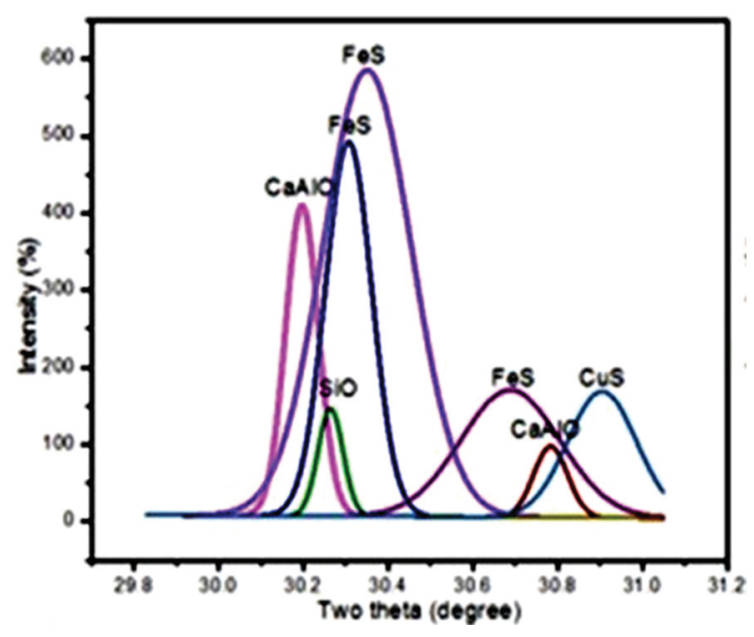

(a)

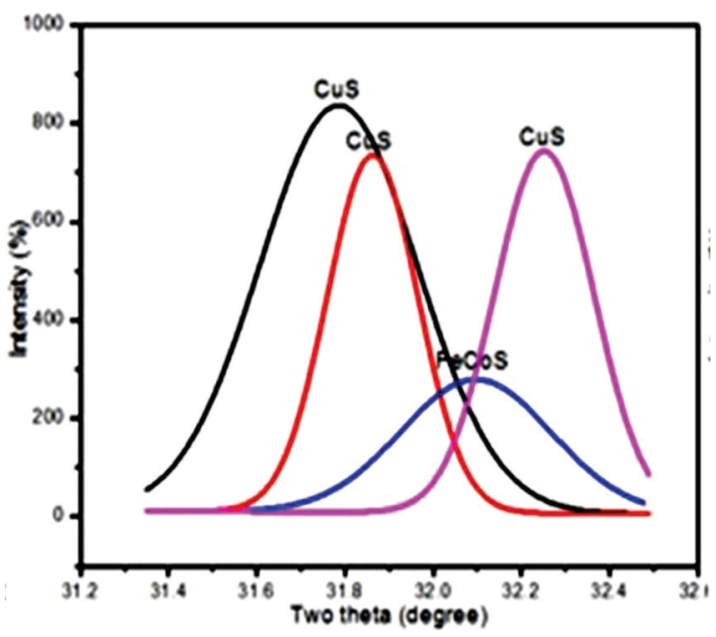

(b)

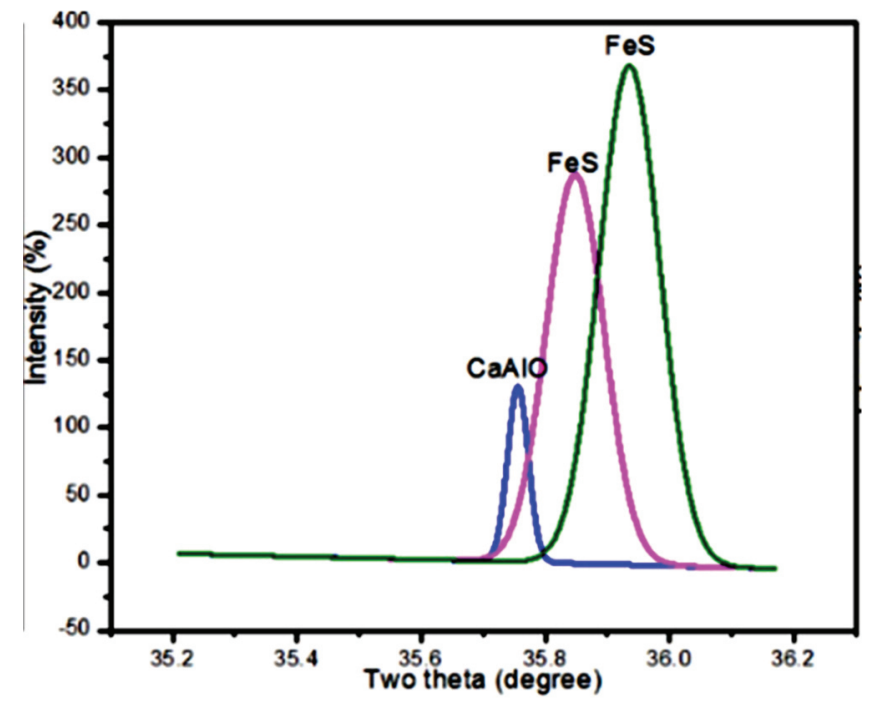

(c)

Figure $4(a, b, c) X R D$ of the copper matte produced

According to the thermodynamics prediction $\mathrm{Cu}_{2} \mathrm{~S}$ should have formed in lieu and place of CuS. But, from the $X R D$ results in Figure 4 no $\mathrm{Cu}_{2} \mathrm{~S}$ was observed. From the XRD spectrums, it was observed that $\mathrm{CuS}$ and FeS formed. This was attributed to the fact that $\mathrm{Cu}_{2} \mathrm{~S}$ is favored by the reaction between $\mathrm{Cu}_{2} \mathrm{O}$ according to the following reaction:

$\mathrm{Cu}_{2} \mathrm{O}+\mathrm{SO}_{2}=\mathrm{Cu}_{2} \mathrm{~S}+1.5 \mathrm{O}_{2}$

However, it should be noted that the copper identified in the slag sample was $\mathrm{CuO}$ not $\mathrm{Cu}_{2} \mathrm{O}$. Therefore, the copper sulphide that formed was driven according to reaction (2). The conversion of $\mathrm{FeO}$ took place according to reaction (3). $\mathrm{FeS}_{2}$ was not present since at the working temperature of $1400{ }^{\circ} \mathrm{C} \mathrm{FeS}$ is more stable than $\mathrm{FeS}_{2}$. This was therefore in line with thermodynamic predictions. 
It was therefore important to state that the addition of gypsum did sulfurize copper oxide and iron oxide that were present in the head sample. Although the amount of gypsum was not varied, it could be seen that sulfurization took place. The amount of matte was very low, hence the small metallic grains were placed on a small sample holder to run the XRD.

The exercise was quite difficult because the separation between the small pellets of metal and the subsequent slag was laborious. This could also be due to the fact that the moving of $\mathrm{FeO}$ from initial slag through reduction to matte in FeS form further modifies the composition of final new slag.

The final slag would therefore be rich in $\mathrm{CaO}$ and $\mathrm{SiO}_{2}$ since $\mathrm{FeO}$ has decreased then increasing the viscosity of the final slag. As a consequence, the separation of matte and new slag was difficult as miscibility was high. Similar observations were made in previous work [15].

With regard to zinc, it was not present in the final product since during reduction zinc is presumed to have evaporated and escaped in the off gas and reoxidized back to $\mathrm{ZnO}$ in the dust. The dusts were not collected to confirm this.

\section{CONCLUSION}

During this investigation it was observed the following:

1) The collection of copper oxide present in the copper slag into the matte was possible. The copper sulphide was present as $\mathrm{CuS}$ not as $\mathrm{Cu}_{2} \mathrm{~S}$ since copper oxide in the head sample slag was found to be $\mathrm{CuO}$ not $\mathrm{Cu}_{2} \mathrm{O}$. The identification of phases was made possible with the use of OriginPro 8.5 software.

2) Gypsum collected from hydrometallurgical plants, during iron removal with the addition of milk of lime where sulphates solutions were used, could be efficiently used as sulfurizing agent instead of stockpiling them where they become hazardous materials. The risk of formation of sulfuric acid that potentially could form during rainy season or wet conditions due to the reaction between gypsum and water has been lowered. Consequently, gypsum was valorised as ingredient in the formation of copper matte.

3) Although the copper slag contained high amount of silica while containing valuable copper, the formation of copper matte was possible since the addition of gypsum played efficiently the important role in the modification of the basicity and as a source of sulphur. The miscibility of the final slag produced was evident. This was attributed to the move of iron oxide to the matte therefore favouring the increase in percentage of calcium oxide and silica.

\section{ACKNOWLEDGEMENTS}

\section{The author would like to thank Gecamines (from the DRC) for providing the copper slag sample and their support and acceptation to collaborate with us.}

\section{REFERENCES}

[1] YU, L, CHEN, Y. TANG, C., YANG, S., HE, J. and TANG, M. Co-treatment of waste smelting slags and gypsum waste via reductive- sulfurizing smelting for valuable metals recovery. Journal of Hazardous materials [Online]. 2016. pp. 402-412. [viewed 2018-10-14]. From: DOI:10.1016/j.jhazmat.2016.10.028.

[2] KASONDE, M., MUKONGO, T. and MUTOMBO, I. Cleaning of a copper matte smelting slag from water jacket furnace by direct reduction of heavy metals. Journal of Hazardous Materials [Online]. 2009. vol. 164, issue 2-3, pp. 856- 862. From DOI:10.1016/j.jhazmat.2008.08.107

[3] POTISZ, A., VAN HULLEBUSCH, E.D. and KIERCZAC, J. Perspectives regarding the use of metallurgical slags as secondary metal resources - A review of bioleaching approaches. Journal of Environmental Management [Online]. 2018, vol. 219, pp. 138-152. [viewed 2019-04-10]. From: DOI: 10.1016/j.jenvman.2018.04.083 
[4] MIKODA, B., POTISZ, A. and KMIECIK, K. Bacterial leaching of critical metal values from polish copper metallurgical slags using acidothiobacillus thiooxidants. Journal of Environmental Management [Online]. 2019. vol. 236, pp. 436-455. [viewed 2019-06-02]. From: DOI:10.1016/j.jenvman.

[5] CHAUKE, N., WA KALENGA, M.K. and NHETA, W. Use of waste gypsum from hydrometallurgical plant for the recovery of nickel from a nickel slag by sulfurization. In Material Science and Technology Conference 2018 (MS\&T18), 2018, Columbus, Ohio USA, pp. 1070- 1080.

[6] YANG, Y., ZHONG, Q., JIANG, T., LI, Q. and XU, B. Viscosity property of gold-antimony smelting slags by blast furnace Gerardo R. F. In 6th International Symposium on High-Temperature Metallurgical, 2015, Walt Disney world. Orlando, Florida, USA, pp. 273-280.

[7] GUO, Zhengqi, ZHU Deqing, PAN Jian, WU, Tengjiao and ZHANG, Feng. Improving beneficiation of copper and iron from copper slag by modifying the molten copper slag. Metals [online]. 2018. vol. 86, no. 6, pp. 1-17. [viewed 2018-10-13]. From: doi:10.3390/met6040086

[8] DIMITRIJEVIC, Mile D., UROSEVIC, Daniela M., JANKOVIC, Zoran D. and MILIC, Snezana M. Recovery of copper from smelting slag by sulfation roasting and water leaching. In Physicochem. Probl. Mineral Processing. 2016. vol. 52, issue 1, pp. 409-421.

[9] ALTUNDOGAN H.S. and TUMEN F. Metal recovery from copper converter slag by roasting with ferric sulfate. Hydrometallurgy.1997. vol. 44, issue 1-2, pp. 261-267.

[10] NADIROV, R., SYZDYKOVA, L. and ZHUSSUPOVA, A. Copper smelter slag treatment by ammonia solution: Leaching process optimization. J. Cent. South Univ. 2017. vol. 24, p. 2799. [viewed 2018-10-13]. From: DOI:10.1007/s11771-017-3694-3

[11] MUHLARE, T. A. and GROOT, D. R. Recovery of copper from reverberatory copper slag and production of a leach residue used as a portland cement additive. In Copper Cobalt Africa, incorporating the 8th Southern African Base Metals Conference 2015. Livingstone, pp. 247-255.

[12] BANZA, A., GOCK, E., and KONGOLO, K. Base metals recovery from copper smelter slag by oxidising leaching and solvent extraction. Hydrometallurgy. 2002. vol. 67, issue 1-3, pp. 63-69.

[13] ARSLAN, C and ARSLAN, F. Recovery of copper, cobalt, and zinc from copper smelter and converter slags. Hydrometallurgy. 2002. vol. 67, issue 1-3, pp. 1-7.

[14] KAYEMBE, J.N, WA KALENGA, M.K. and NYEMBWE, D.K. Effect of basicity and ferrosilicon addition matte formation from Ge-bearing copper slag. In Material Science and Technology Conference 2018 (MS\&T18), 2018. Columbus, Ohio USA, pp. 1126-1131.

[15] LI, Yun, CHEN, Yongming, TANG, Chaobo, YANG, Shenghai, HE, Jing and TANG, Motang. Co-treatment of waste smelting slags and gypsum wastes via reductive-sulfurizing smelting for valuable metals recovery. Journal of Hazardous Materials [Online]. 2016. vol. 322, part B, pp. 402-412. [viewed 2018-10-13]. From DOI: 10.1016/j.jhazmat.2016.10.028 